\title{
PENGARUH DOSIS INOKULAN ALAMI (EKTOMIKORIZA) TERHADAP PERTUMBUHAN SEMAI TENGKAWANG (Shorea pinanga)
}

\author{
Growth and Yield Model of Meranti on the Selective Cutting and Line Planting System \\ Gusmiaty $^{1 \otimes}$, Muh. Restu ${ }^{1}$ dan Ayu Lestari ${ }^{2}$ \\ ${ }^{1}$ Laboratorium Silvikultur, Fakultas Kehutanan, Universitas Hasanuddin, \\ Jl. Perintis Kemerdekaan Km. 10 Tamalanrea, Makassar 90245 \\ ${ }^{2}$ Alumni Fakultas Kehutanan, Universitas Hasanuddin
}

\begin{abstract}
This research aimed to know the effect of some doses of natural inoculants on the growth of Shorea pinanga seedling. The research was carried out with several steps including seed provision, inoculation of ectomycorrhyza, planting and maintenance in the nursery. The result of the research showed that height and number of branches were different at the significant level of $5 \%$, while diameter and number of leaves were not significantly different. The natural inoculants dose of $15 \mathrm{~g}$ showed the best growth in response to the increment of height, diameter, and number of leaves, while that of $20 \mathrm{~g}$ showed the best in the number of branches increment.
\end{abstract}

Key words: Shorea pinanga, ectomycorrhyza, seedling, natural inoculants

\section{PENDAHULUAN}

Tengkawang adalah salah satu jenis tumbuhan khas Kalimantan Barat yang biasanya tumbuh di kawasan hutan. Biji tengkawang sebagai hasil hutan bukan kayu memainkan peranan penting sebagai sumber pendapatan. Tengkawang juga menyumbang dalam keanekaragaman produksi hutan dan menjadi alternatif yang menarik secara ekonomi terhadap pemanfaatan hutan hujan tropis selain untuk produksi kayu. Penanaman dan budidaya pohon-pohon tengkawang yang bernilai tinggi secara berkelanjutan merupakan sebuah kontribusi untuk melestarikan keanekaragaman hayati dan untuk meningkatkan pendapatan masyarakat (Irwanto, 2011).

Praktek pengelolaan hutan yang tidak memerhatikan aspek kelestarian sumberdaya hutan akan berakibat terhadap menurunnya luas hutan primer dan diduga berpengaruh terhadap penurunan keragaman genetik serta kemungkinan punahnya jenis pohon penghasil tengkawang. Salah satu upaya yang perlu dilakukan untuk menghindari

\footnotetext{
Diterima: 10 April 2012; Disetujui: 2 Juli 2012

$\square$ Penulis korespondensi (corresponding author): umyhody@ymail.com
}

punahnya jenis pohon penghasil tengkawang adalah dengan aplikasi teknologi budidaya yang memanfaatkan mikroorganisme jenis ektomikoriza.

Beberapa hasil penelitian menunjukkan adanya peningkatan dan perbaikan pertumbuhan tanaman setelah diberikan inokulasi fungi ektomikoriza bila dibandingkan dengan tumbuhan yang tidak memiliki simbiosis dengan ektomikoriza (Riniarti, 2002). Oleh karena itu fungi ektomikoriza mempunyai peranan penting dalam meningkatkan kualitas pertumbuhan khususnya pada tumbuhan jenis tengkawang yang sangat bergantung pada ektomikoriza (Omon, 2008).

Sampai saat ini penelitian yang menyajikan informasi budidaya pohon penghasil tengkawang untuk memperoleh jenis pohon unggul melalui perlakuan-perlakuan teknologi budidaya yang tepat mulai dari penyediaan bibit, pemberian perlakuan dan pemeliharaan di persemaian, teknik penanaman bibit unggul dan cara pemeliharaannya di lapangan masih sangat terbatas. Dengan demikian perlu dilakukan penelitian mengenai pemanfaatan inokulan alami (ektomikoriza) untuk menghasilkan bibit tengkawang yang berkualitas, melalui pemberian dosis yang efektif untuk meningkatkan pertumbuhan bibit $S$. pinanga di persemaian. 


\section{METODE PENILITIAN}

Penelitian ini dilaksanakan di rumah kaca (Green House), Balai Besar Penelitian Dipterokarpa Samarinda Provinsi Kalimantan Timur.

\section{Prosedur Kerja}

Pengambilan Inokulan Alami dan Cabutan di Lapangan

Pengambilan inokulan alami disekitar akar halus dengan menggunakan sekop/cangkul dengan kedalaman 10-15 cm. Inokulan alami diambil lalu dimasukkan ke dalam kantong plastik. Pada saat pengambilan cabutan, dilakukan pengukuran terhadap suhu, kelembaban udara, dan intensitas cahaya. Hal ini dilakukan guna mengetahui faktorfaktor mikro yang memengaruhi pertumbuhan inokulan (ektomikoriza).

\section{Penyiapan bibit dan Inokulasi Mikoriza}

Anakan hasil cabutan yang diambil di lapangan disemai ke dalam polybag dengan 5 (Lima) perlakuan inokulan yaitu :

1. Media tanam tanpa inokulan (kontrol)

2. Media tanam +5 gram inokulan

3. Media tanam +10 gram inokulan

4. Media tanam +15 gram inokulan

5. Media tanam +20 gram inokulan

\section{Pemeliharaan semai}

Pemeliharaan dilakukan secara rutin meliputi: penyiraman, penyiangan, pembukaan naungan/ sarlon sesuai dengan kebutuhan sinar matahari bagi pertumbuhan bibit, dan lain-lain.

\section{Pengamatan dan Pengukuran}

Pengamatan dan pengukuran bibit dilakukan setiap 2 minggu sekali selama 3 bulan. Variabel yang diamati dalam penelitian ini adalah tinggi bibit $(\mathrm{cm})$, diameter bibit $(\mathrm{mm})$, jumlah daun, dan jumlah cabang yang muncul.

\section{Pengukuran tinggi bibit}

Pengukuran tinggi bibit dilakukan dengan menggunakan mistar diukur mulai dari pangkal batang sampai titik tumbuh teratas selama 3 bulan. Pengukuran dilakukan terhadap semua unit percobaan.

\section{Pengukuran diameter batang bibit}

Pengukuran diameter batang menggunakan kaliper, pengukuran dilakukan terhadap semua unit percobaan.

\section{Pengamatan pertambahan jumlah daun}

Pengamatan dilakukan terhadap semua unit percobaan

\section{Pengamatan pertambahan jumlah cabang}

Pengamatan dilakukan terhadap semua unit percobaan.

\section{Pengolahan data}

\section{Rancangan Percobaan}

Rancangan penelitian dengan menggunakan metode Rancangan Acak Lengkap (RAL) dengan perlakuan media tanam sebanyak 5 perlakuan setiap perlakuan diulang sebanyak 20 kali, sehingga total unit percobaan sebanyak 100 unit.

\section{Analisis Data}

Untuk mengetahui pengaruh beberapa perlakuan terhadap pertambahan tinggi, diameter, cabang baru dan jumlah daun baru dilakukan uji sidik ragam Anova, kemudian dilakukan uji lanjut BNJ. Tabel hasil data pengukuran dan pengamatan terhadap bibit $S$. pinanga yang digunakan dalam analisis ini, disajikan pada Lampiran 8, bibit yang hidup pada setiap perlakuan masing-masing P0 (5 ulangan), P5 (10 ulangan), P10 (16 ulangan), P15 (19 ulangan) dan P20 (15 ulangan). Rumus uji lanjut BNJ untuk ulangan yang tidak sama adalah sebagai berikut:

$$
B N J_{\alpha}=\mathrm{q}(\mathrm{a}, \mathrm{p}, \mathrm{dbgalat}) \cdot \sqrt{\frac{1}{2}} K T G\left(\frac{1}{n 1}+\frac{1}{n 2}\right)
$$

Keterangan:

$$
\begin{array}{ll}
\alpha & =\text { taraf nyata } 5 \% \\
\mathrm{p} & =\text { jumlah perlakuan }
\end{array}
$$

$\mathrm{db}$ galat $=$ derajat bebas galat

KTG = kuadrat tengah galat

$\mathrm{n} 1=$ jumlah ulangan perlakuan 1

$\mathrm{n} 2=$ jumlah ulangan perlakuan 2

\section{HASIL DAN PEMBAHASAN}

\section{Pertambahan Tinggi Semai S. pinanga}

Berdasarkan hasil analisis varian (anova) menunjukkan bahwa faktor dosis inokulan alami berbeda nyata pada taraf uji $5 \%$ terhadap pertambahan tinggi semai S. pinanga. Uji lanjutan Uji Beda Nyata Jujur (BNJ) yang diperoleh, disajikan pada Tabel 1. Tabel 1 menunjukkan bahwa perlakuan 
Table 1. Hasil uji BNJ rata-rata pertambahan tinggi semai S. pinanga

\begin{tabular}{ccc}
\hline Perlakuan & $\begin{array}{c}\text { Rata-rata } \\
\text { pertumbuhan } \\
\text { tinggi }(\mathrm{cm})\end{array}$ & Deskripsi \\
\hline P20 & 2,4 & $\mathrm{a}$ \\
P0 & 3,3 & $\mathrm{ab}$ \\
P5 & 3,8 & $\mathrm{abc}$ \\
P10 & 4,4 & $\mathrm{bcd}$ \\
P15 & 4,8 & $\mathrm{~cd}$ \\
\hline Keterangan: huruf sama menunjukkan tidak ada pengaruh \\
\multicolumn{2}{c}{ yang signifikan pada taraf $5 \%$}
\end{tabular}

$\mathrm{P} 10$ dan $\mathrm{P} 15$ berbeda tidak nyata dengan rata-rata pertambahan tinggi sebesar 4,4 dan $4,8 \mathrm{~cm}$. Kedua perlakuan tersebut berbeda nyata dengan perlakuan $\mathrm{P} 0$, P5, dan P20 dengan rata-rata pertambahan tinggi P0 $(3,3 \mathrm{~cm}), \mathrm{P} 5(3,8 \mathrm{~cm})$ dan P20 $(2,4 \mathrm{~cm})$.

Perbedaan respon rata-rata pertambahan tinggi dari kelima perlakuan inokulan alami semai S. pinanga pada umur 3 (tiga) bulan dapat lebih jelas dilihat pada Gambar 1. Pada Gambar 1 terlihat bahwa respon pertambahan tinggi semai yang terbaik dengan adanya pemberian inokulan alami adalah dosis $15 \mathrm{~g}$, sedangkan pada dosis $20 \mathrm{~g}$ ratarata tinggi tanaman mulai menurun. Hal tersebut disebabkan karena pada pemberian dosis inokulan lebih dari $15 \mathrm{~g}$ diduga dapat menurunkan serapan unsur hara yang dibutuhkan tanaman sehingga pertumbuhan tanaman terhambat. Hal ini sesuai pendapat Musfal (2010) yang menyatakan bahwa pemberian inokulan (mikoriza) lebih dari $15 \mathrm{~g}$ akan menurunkan serapan P. Penurunan serapan P pada pemberian mikoriza dosis tinggi diduga berkaitan dengan kompetisi inokulan itu sendiri dalam menginfeksi akar dan kemampuan akar untuk menyerap P yang ada dalam larutan tanah.

Unsur-unsuryang berguna dalam meningkatkan pertumbuhan tinggi tanaman, seperti $\mathrm{P}, \mathrm{Cu}$, dan $\mathrm{Zn}$ yang terkandung dalam inokulan alami dapat diserap dengan baik oleh tanaman dengan bantuan mikoriza (fungi) yang diinokulasikan pada media pada dosis $15 \mathrm{~g}$, ini dibuktikan dengan adanya kolonisasi hifa dan spora pada akar semai $S$. pinanga. Fungi Mikoriza menginfeksi akar tanaman kemudian memproduksi jalinan hifa secara intensif, sehingga tanaman yang bermikoriza akan mampu meningkatkan kapasitasnya dalam penyerapan unsur hara. Menurut David \& Nilsen (2000) dalam Dewi (2007), unsur-unsur hara yang diserap tanaman yang terinfeksi fungi mikoriza adalah

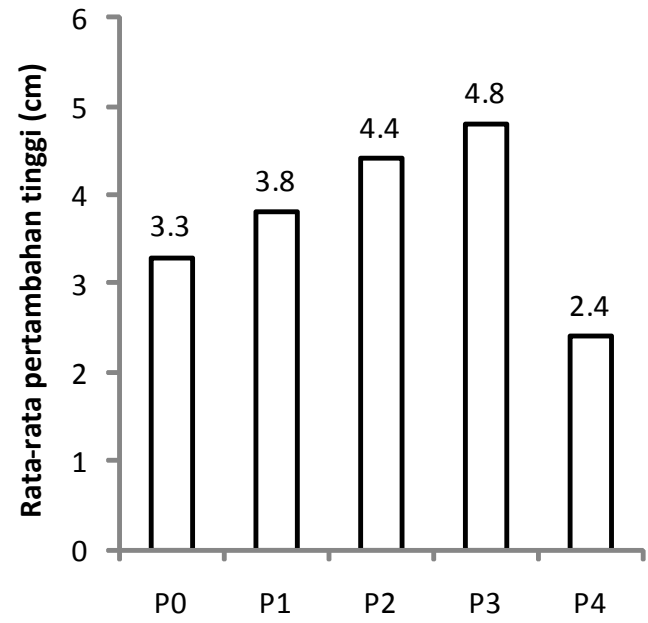

Gambar 1. Rata-rata pertambahan tinggi semai S. pinanga umur tiga bulan

$P$ dan unsur mikro seperti $\mathrm{Cu}, \mathrm{Zn}$, dan $\mathrm{B}$ dapat ditingkatkan penyerapannya pada tanaman yang berasosiasi dengan mikoriza.

Gardner et al., (1991) dalam Suherman et al. (2009) menyatakan bahwa meristem ujung menghasilkan sel-sel baru di ujung akar atau batang mengakibatkan tumbuhan bertambah tinggi atau panjang. Tinggi tanaman merupakan indikator pertumbuhan atau sebagai parameter yang digunakan untuk mengukur pengaruh lingkungan atau perlakuan karena sifatnya sensitif terhadap faktor lingkungan.

\section{Pertambahan Diameter Batang Semai $S$. pinanga}

Hasil analisis varian diperoleh menunjukkan faktor perlakuan inokulan alami tidak berbeda nyata pada taraf uji $5 \%$ terhadap pertambahan diameter batang semai $S$. pinanga. Hal ini menunjukkan bahwa masing-masing perlakuan memberikan pengaruh yang tidak nyata terhadap pertambahan diameter tanaman. Oleh karena itu uji perlakuan dosis inokulan alami dengan menggunakan Uji BNJ pada diameter batang ini tidak perlu dilanjutkan lagi.

Perbedaan respon rata-rata pertambahan diameter dari kelima perlakuan inokulan alami semai S. pinanga pada umur 3 (tiga) bulan dapat lebih jelas dilihat pada Gambar 2. Pada Gambar 2 terlihat bahwa respon rata-rata pertambahan diameter relatif sama dari kelima perlakuan, sedangkan rata-rata pertambahan diameter terbaik pada dosis $15 \mathrm{~g}$, hal ini diduga pada dosis $15 \mathrm{~g}$ unsur hara yang diserap 


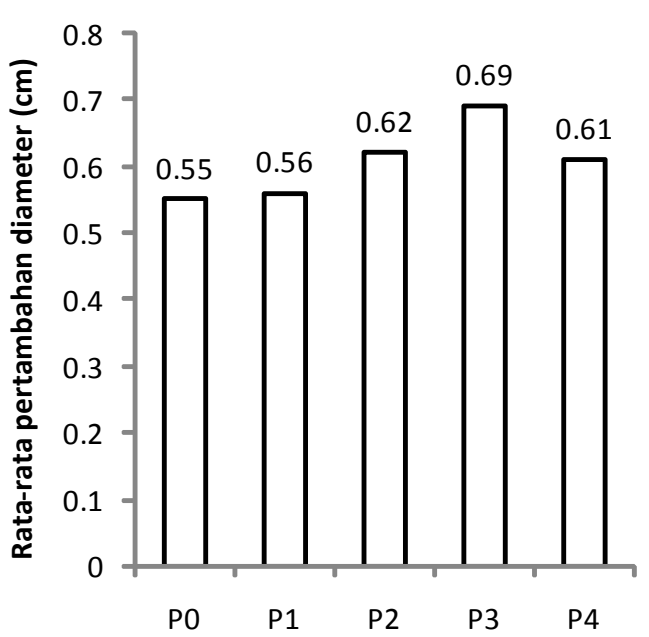

Gambar 2. Rata-rata pertambahan diameter batang $S$. pinanga pada umur tiga bulan

dengan bantuan fungi mikoriza pada inokulan alami mencukupi sehingga mempercepat pertumbuhan kambium. Hal ini sesuai pendapat Agustina (1990) dalam Nirwana (2006) yang menyatakan bahwa, fungi mikoriza (inokulan alami) juga meningkatkan penyerapan berbagai unsur hara yang cukup untuk digunakan sebagai penyusun karbohidrat dalam proses fotosintesis. Karbohidrat yang dihasilkan dalam fotosintesis dalam jumlah yang cukup, menyebabkan aktivitas pembelahan dan penebalan sel-sel jaringan tanaman dalam proses diferensiasi menjadi lebih cepat sehingga pertumbuhan kambium berjalan lebih cepat, yang tampak dalam pertambahan diameter batang tanaman.

\section{Pertambahan Jumlah Daun Semai S. pinanga}

Berdasarkanhasilanalisisvarianyang diperoleh, faktor perlakuan inokulan alami tidak berbeda nyata pada taraf uji $5 \%$ terhadap pertambahan jumlah daun semai S. pinanga, Hal ini menunjukkan bahwa masing-masing perlakuan memberikan pengaruh yang tidak nyata terhadap pertambahan jumlah daun. Oleh karena itu uji perlakuan dosis inokulan alami dengan menggunakan Uji BNJ tidak perlu dilanjutkan lagi.

Perbedaan rata-rata pertambahan jumlah daun baru dari kelima perlakuan inokulan alami semai $S$. pinanga pada umur 3 (tiga) bulan dapat lebih jelas dilihat pada Gambar 3. Pada Gambar 3 terlihat bahwa jumlah daun pada perlakuan $15 \mathrm{~g}$ nyata lebih tinggi dibandingkan $20 \mathrm{~g}$, hal ini diduga pada dosis tinggi $(20 \mathrm{~g})$ dapat menurunkan penyerapan unsur hara pembentuk daun khususnya nitrogen,

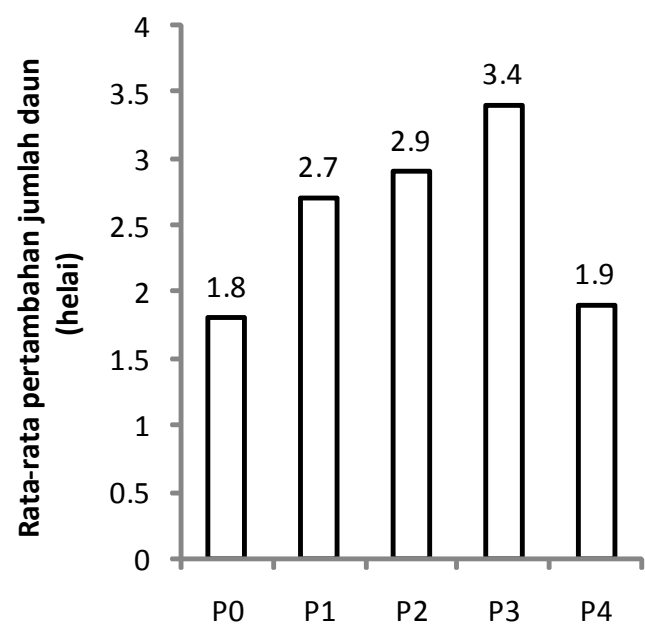

Gambar 3. Rata-rata pertambahan jumlah daun $S$. pinanga pada umur tiga bulan

yang mengakibatkan pembentukan daun terhambat. Sehingga pemberian inokulan alami $15 \mathrm{~g}$ dianggap dosis standar yang dapat berpengaruh terhadap pertumbuhan daun secara maksimal.

Menurut Setiadi (2006) dalam Rossiana (2010), fungi mikoriza yang terdapat pada inokulan alami mampu meningkatkan serapan hara berupa $\mathrm{Mg}, \mathrm{Mn}, \mathrm{Cl}$. Unsur Mg berperan sebagai penyusun klorofil, unsur $\mathrm{Mn}$ berperan sebagai elemen struktural kloroplas, sedangkan $\mathrm{Cl}$ berpengaruh terhadap evolusi $\mathrm{O}_{2}$ di dalam kloroplas. Keberadaan unsur ini dapat mempercepat pembentukan daun pada tanaman, jumlah daun pada tiap tanaman menunjukkan intensitas pertumbuhan.

Rosmakam \& Yuwono (2002) dalam Karmilasanti \& Andrean (2001) menyatakan bahwa jenis legum dengan bintil akar (mikoriza) mempunyai kemampuan penyerapan $\mathrm{N}$ lebih tinggi dibandingkan jenis lainnya. Over dosis dengan pemberian mikoriza akan mengakibatkan tanaman mudah rebah karena sistem perakaran yang sempit. Sementara jika pemberiannya di bawah optimal akan menyebabkan naiknya asimilasi amonia dan kadar protein dalam daun, serta pertumbuhan akan terhambat.

\section{Pertambahan Jumlah Cabang Semai S. pinanga}

Berdasarkanhasilanalisis varianyang diperoleh, faktor perlakuan dosis inokulan alami berbeda nyata pada taraf uji $5 \%$ terhadap jumlah cabang semai S. pinanga, selanjutnya dilakukan uji BNJ terhadap perlakuan yang berbeda nyata disajikan pada Tabel 2. Tabel 2 menunjukkan inokulasi perlakuan P15 
Table 2. Hasil uji BNJ rata-rata pertambahan jumlah cabang semai S. pinanga

\begin{tabular}{ccc}
\hline Perlakuan & $\begin{array}{c}\text { Rata-rata } \\
\text { Pertambahan jumlah } \\
\text { cabang }(\mathrm{cm})\end{array}$ & Deskripsi \\
\hline P0 & 0,20 & $\mathrm{a}$ \\
P5 & 0,30 & $\mathrm{ab}$ \\
P10 & 0,81 & $\mathrm{bc}$ \\
P20 & 1,05 & $\mathrm{bcd}$ \\
P15 & 1,20 & $\mathrm{~cd}$ \\
Keterangan: huruf sama menunjukkan tidak ada pengaruh \\
\multicolumn{3}{c}{ yang signifikan pada taraf $5 \%$}
\end{tabular}

dan P20 berbeda tidak nyata dan berbeda nyata terhadap perlakuan tanpa mikoriza, P5 dan P10. Rata-rata jumlah cabang semai $S$. pinanga yang diinokulasi dosis 15 dan $20 \mathrm{~g}$ adalah 1,05 dan 1,20, nilai ini lebih tinggi dibandingkan dengan perlakuan dosis $5 \mathrm{~g}(0,30)$, perlakuan $10(0,81)$ dan tanpa mikoriza $(0,20)$.

Perbedaan rata-rata pertambahan jumlah cabang baru pada perlakuan dosis inokulan alami semai $S$. pinanga pada umur 3 (tiga) bulan dapat lebih jelas dilihat pada Gambar 4 . Pada Gambar 4 terlihat bahwa pengaruh inokulan alami terhadap rata-rata pertambahan cabang baru semakin meningkat dengan bertambahnya dosis inokulan dari P0 sampai P20, namun pertambahan cabang yang paling banyak terdapat pada dosis $20 \mathrm{~g}$, sehingga proses pembentukan cabang dianggap membutuhkan unsur-unsur hara dengan kadar atau dosis inokulan tertentu.

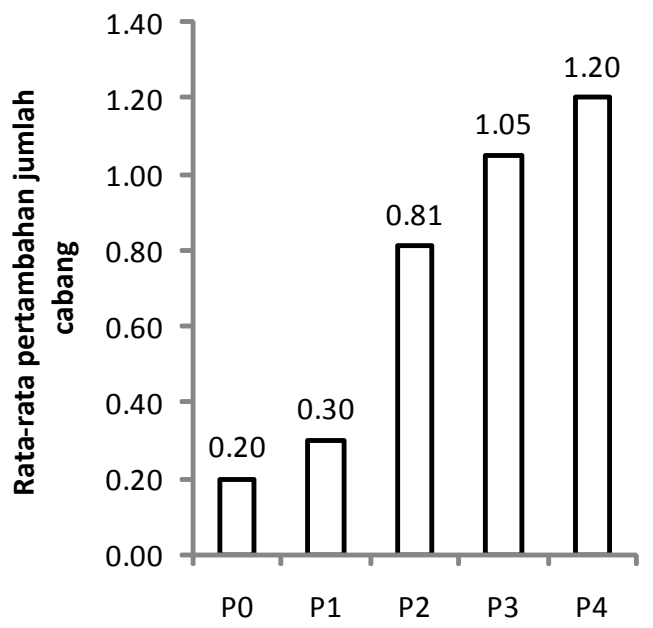

Gambar 4. Rata-rata pertambahan jumlah cabang Semai S. pinanga pada umur tiga bulan
Hal ini sesuai dengan penelitian Karmilasanti \& Andrean (2011) yang menyatakan bahwa pengaruh perlakuan inokulan alami terhadap pembentukan cabang baru pada tengkawang jenis $S$. macrophylla memberi hasil signifikan pada dosis tertentu yaitu dosis $15 \mathrm{~g}$.

\section{KESIMPULAN}

Berdasarkan penelitian yang telah dilakukan, maka dapat disimpulkan bahwa:

1. Perlakuan dosis inokulan alami (ektomikoriza) memberikan pengaruh nyata terhadap pertambahan tinggi, dan jumlah cabang semai S. pinanga.

2. Perlakuan yang paling efektif dalam meningkatkan pertambahan tinggi, diameter, dan jumlah daun semai $S$. pinanga adalah pada dosis $15 \mathrm{~g}$.

3. Perlakuan yang paling efektif dalam meningkatkan pertambahan jumlah cabang pada semai S. pinanga adalah pada dosis 20 g.

\section{DAFTAR PUSTAKA}

Dewi, R. I. 2007. Peran Prospek dan Kendala dalam Pemanfaatan Endomikoriza. Bandung. Fakultas Pertanian Universitas Padjadjaran Jatinangor.

Irwanto. 2011. Kajian terhadap jenis, kegunaan dan konservasi tumbuhan tengkawang dari perspektif sosial budaya masyarakat di Provinsi Kalimantan Barat. http://www. scribd.com/doc/51202069/MAKALAH-UTS [ d i a k s e s tanggal 16 juni 2011]

Karmilasanti dan F. Andrean. 2011. Silvikultur intensif jenis Dipterokarpa. Laporan hasil penelitian. Samarinda. Balai Besar Penelitian Dipterokarpa.

Musfal. 2010. Potensi cendawan mikoriza arbuskula untuk meningkatkan hasil tanaman jagung. Jurnal Litbang Pertanian 29(4).

Nirwana. 2006. Aplikasi Mikoriza Vesikular Arbuskular (MVA) terhadap Pertumbuhan Semai Bitti Vitex cofassus Reinw. Makassar. Universitas Hasanuddin.

Omon, M. 2008. Pengaruh dosis tablet mikoriza terhadap pertumbuhan dua jenis meranti merah asal benih dan stek di HPH PT. ITCIKU, Balikpapan, Kalimantan Timur. Jurnal Info Hutan Vol V No.4.

Riniarti, M. 2002. Perkembangan kolonisasi ektomikoriza dan pertumbuhan semai dipterocarpaceae dengan pemberian asam oksalat dan asam humat serta inokulasi ektomikoriza [Tesis]. Pasca Sarjana. IPB. 
Rossiana, N. 2010. Penurunan kandungan logam berat dan pertumbuhan tanaman sengon Paraserianthes falcataria $L$ (Nielsen). Bandung. Universitas Padjadjaran.

Suherman, C., A. Nuraini dan S. Rosniawati. 2009. Pemanfaatan Cendawan Mikoriza Arbuskular (CMA) Serta Media
Campuran Subsoil dan Kompos pada Pembibitan Kelapa Sawit (Elaeis guieensis) Kultivar Sungai Pancur 2 (SP2). http://pustaka.unpad.ac.id/wpcontent/uploads/2009/10/ pemanfaatan_cendawan_mikroriza_arbuskular_serta media_campuran_subsoil.pdf.html [diakses tanggal $\overline{9}$ Januari 2011]. 